\title{
Research on China's Green Finance Promoting Sustainable Economic Development
}

\author{
Kai Xiong ${ }^{1, a^{*}}$, Yijun $\mathrm{Yao}^{2, \mathrm{~b}}$ \\ ${ }^{1}$ Business School of Jianghan University, Manufacturing Industry Development Research Center on Wuhan city circle, Wuhan City, \\ Hubei Province, P.R. China \\ ${ }^{2}$ Business School of Jianghan University, 2020 Postgraduate of Accounting Professional Master, Wuhan City, Hubei Province, P.R. \\ China
}

\begin{abstract}
With China's economic development entering a new normal, green finance has become a new direction to explore the sustainable development of economy in the supply side structural reform task of "three removal, one reduction and one compensation". Firstly, this paper analyzes the concept of green finance and its development status. Secondly, taking green credit as an example, this paper makes an empirical study on the contribution of green finance to sustainable economic development. Finally, according to the results of empirical research, some suggestions including increasing the application proportion of green finance, improving green financial products and business model and forming a market mechanism for green finance to promote green development independently, are put forward to improve the sustainable development of green finance in China.
\end{abstract}

\section{Introduction}

In the sixties and seventies of last century, based on the worry and doubt about the development mode of developed countries, the club of Rome deeply discussed the fundamental issues related to the future of human development. They realized that the development mode of "pollution first, treatment later" hindered the sustainable development of economy. In recent years, although China's social economy has developed rapidly, the situation of resources and environment has become increasingly severe, the waste of resources has led to exhaustion, the ecological environment has been seriously damaged, causing irreparable heavy losses to people's lives, and is bound to seriously hinder the longterm development of the future economy. Therefore, we must carry out economic structure reform and industrial transformation and upgrading[1]. Finance is the core of the economy, and green finance is frequently mentioned as a hot word in the financial industry. Premier $\mathrm{Li}$ Keqiang proposed in the government work report that we should vigorously develop Inclusive Finance and green finance"; In the 19th National Congress of the Communist Party of China, the principle of speeding up the reform of the ecological civilization system and building a beautiful China was also emphasized, advocating that the society strive to form a new way of production and life of resource conservation and environmental protection. The development of green finance is of great significance to promote the sustainable development of economy. As a bridge between China's financial industry and environmental protection industry, it has become the main path to explore the new direction of China's green economy[2]. In view of this, we need to integrate the existing advantageous resources, formulate the sustainable development mechanism of green finance, give full play to the role of Finance in the economy, improve the overall economic level of our country, improve the quality of people's life, and realize the win-win situation of green water and green mountains and golden mountains and silver mountains.

\section{Overview of green finance}

Green finance is to deal with the worsening global climate, innovate the traditional financial development mode in the aspect of economic development, and play the role of financial market with the goal of protecting human living environment and making efficient use of resources, that is, the financial sector provides investment and financing, project operation, risk management and other market operation means for projects in the field of green environmental protection. The establishment of green financial system aims to improve the return on investment and the availability of financing of green projects, and restrain the investment of polluting projects[3].Green finance promotes technological progress and industrial structure upgrading by guiding capital allocation, so as to enhance the potential of sustainable economic growth [4].Although China's green finance started late, the relevant policy system has been steadily promoted in recent years, and

\footnotetext{
* Corresponding author: ${ }^{\mathrm{a} x k y x @ \text { sina.com }}$

b1336207074@qq.com
} 
remarkable achievements have been made in green credit, green bonds, green insurance and other fields[5].

\subsection{Green credit}

Green credit is a kind of loan to invest in green projects and support environmental improvement. The development scale of green credit in financial market is steadily expanding. Commercial banks should increase their support for green development by means of credit, and give full play to the role of social capital allocation[6]. By the end of 2020, the balance of domestic and foreign currency green loans was 11.95 trillion yuan, an increase of $20.3 \%$ over the beginning of the year. In terms of use, the balance of loans for infrastructure green upgrading industry and clean energy industry were 5.76 and 3.2 trillion yuan respectively, up $21.3 \%$ and $13.4 \%$ respectively from the beginning of the year.

\subsection{Green bond}

Green bonds are debt securities that raise special funds to support green industry projects. Compared with ordinary bonds, green bonds have high sovereign characteristics. In December 2015, the people's Bank of China issued the No. 39 announcement to launch green financial bonds in the inter-bank bond market, which innovated financing channels for financial institutions to raise funds through the bond market to support green industry projects. The growth trend of green bonds is still strong, with a small expansion of issuance scale, ranking at the forefront of the global green bond market. In 2019, China's domestic and foreign green bond issuance amounted to RMB 339.062 billion, with 214 issued, an increase of $26 \%$ and $48 \%$ respectively over 2018 , accounting for $21.3 \%$ of the global green bond issuance in the same period.

\subsection{Green insurance}

Green insurance mainly refers to environmental pollution liability insurance, which is based on the compensation liability of the third party caused by pollution accidents. Green insurance is still in the initial stage of development. With the support of relevant policies, the insurance industry has completed the preliminary exploration work in serving the development of green economy in recent years. With the further development of green finance in the future, green insurance will expand the service field, give full play to the advantage function of insurance economic compensation, guarantee the demand of green industry for risk management, reduce investment risk, stabilize investor confidence, increase investment funds for green projects, and inject vitality into the development of green finance.

\section{Development status of green finance in China}

\subsection{The green financial framework has taken shape}

The government has made an overall plan for the construction of green finance in China, and has successively introduced a series of innovative policies and measures to help the rapid development of green finance, and strive to build a new financial system framework to gradually adapt to the development process of green economy. On August 31, 2016, the guidance on building a green financial system was issued, which strengthened the top-level design of green finance, gradually promoted the construction of relevant policies and systems, stressed that the development of green finance should combine market players with green financial instruments, improve the basic elements of green finance, mobilize and encourage all social capital to participate in the development of green industry, In order to achieve the long-term goal of economic and social sustainable development, we should build a practical and mature market system to support the economic transformation to green.

\subsection{Diversification of green financial entities}

With the strong support of the government, the main body of green finance development presents the trend of diversification, and the increasing market participants promote the sustainable development of green finance. Industrial Bank is the first equatorial bank to set foot in the field of green finance in China, and it is the earliest banking financial institution to carry out professional green financial business in China. The environmental finance department was established in the internal organizational structure of industrial bank to provide comprehensive green financial services. In recent years, insurance, securities and other non bank financial institutions have innovated their products according to the development needs of Green Finance on the basis of maintaining the original product structure.

\subsection{The construction of green credit system is relatively perfect}

In order to encourage the banking industry to actively optimize and adjust the credit capital structure, increase the support for green environmental protection industry, and provide policies and guidance on green credit, such as the guidance on energy conservation and emission reduction credit work issued by CBRC on November 23, 2007, and the guidance on green credit issued on February 24, 2012, etc, To control or even reduce the "two high and one surplus" industry credit scale. These opinions and guidelines promote the banking industry to focus on green credit, guide social resources to pay more attention to environmental protection, and better serve the green development of the real economy. However, due to the current green credit is still in the stage of 
exploration and development, the effect of driving the industry needs to be improved.

\section{An empirical analysis of green finance promoting economic development}

According to the data published on the website of the people's Bank of China, the balance of domestic and foreign currency green loans in China has increased from 5.25 trillion yuan at the end of 2013 to 11.95 trillion yuan at the end of 2020.Therefore, this paper takes the green credit of banks as the representative, collects data, analyzes the correlation between the development of green finance and sustainable economic development by using SPSS software, and determines the following four indicators: the first is the proportion of deposits of financial institutions in GDP. The second is the proportion of green credit of 21 major banks in GDP. The third is the correlation rate of green finance, which reflects the proportion of green financial resources per unit of GDP, expressed by the ratio of the sum of deposits and green credit of financial institutions to GDP. The fourth is the total output value index of Industrial Enterprises above Designated Size, which analyzes and measures whether the use of green credit can promote the efficient increase of enterprise output value.

Based on the national typical economic data from 2013 to 2018, this paper analyzes the impact of green credit on GDP growth and enterprise development. The specific data are as follows: Table 1 and table 2 .

Table 1.Data of various economic indicators (2013-2018) unit: 100 million yuan

\begin{tabular}{|c|c|c|c|c|c|}
\hline year & GDP & Deposits & $\begin{array}{c}\text { Total amount of } \\
\text { green credit }\end{array}$ & $\begin{array}{c}\text { Above scale } \\
\text { Total output value of } \\
\text { industrial enterprises }\end{array}$ & $\begin{array}{c}\text { Green finance } \\
\text { correlation rate }\end{array}$ \\
\hline 2013 & 592963.2 & 1043846.86 & 51983.09 & 1038659.45 & $184.81 \%$ \\
\hline 2014 & 643563.1 & 1138644.64 & 60128.29 & 1107032.52 & $186.27 \%$ \\
\hline 2015 & 688858.2 & 1357021.61 & 70066.13 & 1109852.97 & $207.17 \%$ \\
\hline 2016 & 746395.1 & 1505863.83 & 75046.87 & 1158998.52 & $211.81 \%$ \\
\hline 2017 & 832035.9 & 1641044.22 & 82956.63 & 1133160.76 & $207.20 \%$ \\
\hline 2018 & 919281.1 & 1775226.00 & 82300.00 & 1022241.10 & $202.06 \%$ \\
\hline
\end{tabular}

Table 2. Descriptive statistical characteristics of green finance and economic development data

\begin{tabular}{|l|l|l|l|l|l|}
\hline project & $\begin{array}{l}\text { Number of } \\
\text { samples }\end{array}$ & mean value & $\begin{array}{l}\text { standard } \\
\text { deviation }\end{array}$ & minimum value & Maximum \\
\hline $\begin{array}{l}\text { gross domestic } \\
\text { product }\end{array}$ & 6 & 737182.77 & 272288.39 & 592963.20 & 919281.10 \\
\hline $\begin{array}{l}\text { Deposits in financial } \\
\text { institutions }\end{array}$ & 6 & 1410274.53 & 1339010.38 & 1043846.86 & 1775226.00 \\
\hline $\begin{array}{l}\text { Total amount of } \\
\text { green credit }\end{array}$ & 6 & 70413.50 & 69181.27 & 51983.09 & 82300.00 \\
\hline $\begin{array}{l}\text { Above scale } \\
\text { Total output value of } \\
\text { industrial enterprises }\end{array}$ & 6 & 1094990.89 & 119939.82 & 1022241.10 & 115899852 \\
\hline $\begin{array}{l}\text { Financial correlation } \\
\text { rate }\end{array}$ & 6 & $199.89 \%$ & $25.8 \%$ & $184.81 \%$ & $211.81 \%$ \\
\hline Deposits/GDP & 6 & 1.903 & 0.248 & 1.760 & 2.017 \\
\hline $\begin{array}{l}\text { Total amount of } \\
\text { green credit/GDP }\end{array}$ & 6 & 0.095 & 0.0135 & 0.088 & 0.101 \\
\hline
\end{tabular}

As can be seen from Fig. 1 and 2, GDP, deposits of financial institutions and total amount of green credit have achieved steady growth. The total output value of Industrial Enterprises above designated size has remained stable, while the financial correlation rate index shows a trend of rapid rise at first and then stable.
It reflects that the support of green credit resources per unit GDP is strong, and green finance boosts economic growth. However, the ratio of the total amount of green credit to GDP declined slightly in 2018 due to the growth of GDP in 2018, but the total amount of green credit declined slightly. 


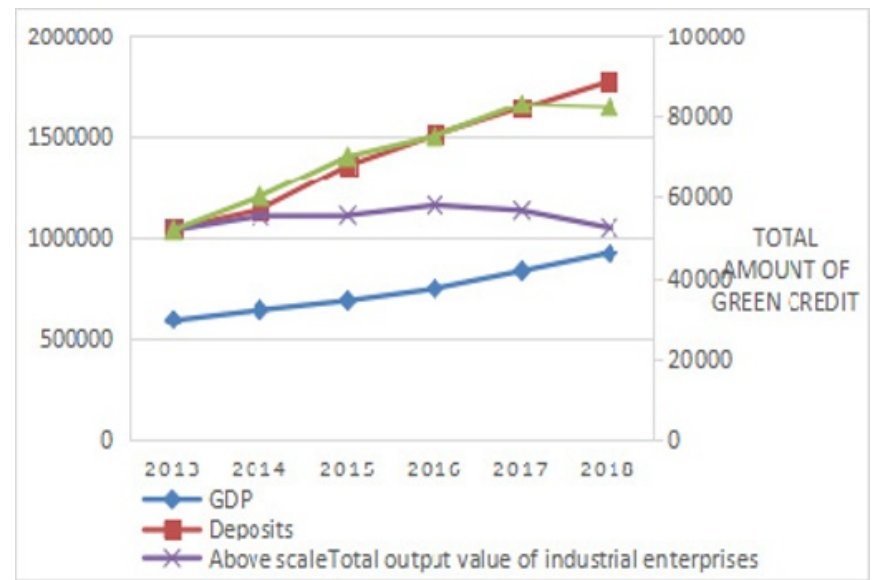

Fig. 1. GDP, deposits of financial institutions, total amount of green credit and total output value of Industrial Enterprises above Designated Size

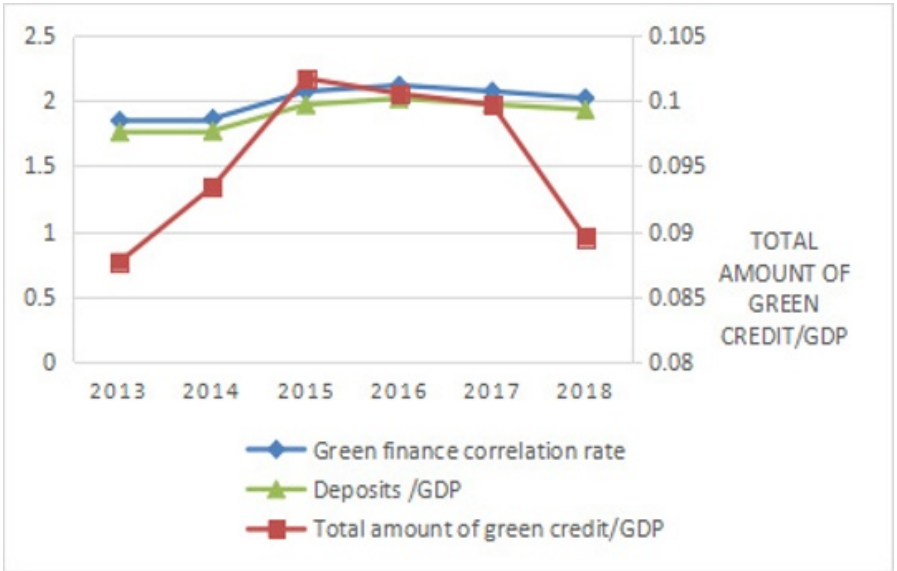

Fig. 2. Data chart of financial correlation rate, deposits of financial institutions / GDP and total green credit / GDP

Based on the selected economic data, SPSS software is used to analyze the correlation of the above four indicators.

Table 3. Correlation test between green finance and economic development

\begin{tabular}{|c|c|c|c|c|}
\hline index & $\begin{array}{c}\text { Total amount of } \\
\text { green credit/GDP }\end{array}$ & $\begin{array}{c}\text { Deposits/G } \\
\text { DP }\end{array}$ & $\begin{array}{c}\text { Above } \\
\text { freen } \\
\text { finance } \\
\text { correlatio } \\
\text { n rate } \\
\text { Total } \\
\text { output } \\
\text { value of } \\
\text { industrial } \\
\text { enterprises }\end{array}$ \\
\hline $\begin{array}{c}\text { Total amount of green } \\
\text { credit/GDP }\end{array}$ & 1 & 1 & 1 & \\
\hline Deposits/GDP & 0.749 & 0.999 & 1 & 1 \\
\hline $\begin{array}{c}\text { Financial correlation } \\
\text { rate }\end{array}$ & 0.772 & 0.616 & 0.642 & \\
\hline $\begin{array}{c}\text { Above scale } \\
\text { Total output value of } \\
\text { industrial enterprises }\end{array}$ & 0.879 & & & \\
\hline
\end{tabular}

Table 3 shows that the correlation coefficients of value of Industrial Enterprises above designated size is particularly close. green credit 's proportion in GDP, deposits of financial institutions'. proportion in GDP and green finance correlation rate with the total output value of Industrial Enterprises above designated size are $0.879,0.616$ and 0.642 respectively. The correlation between the proportion of green credit in GDP and the total output 


\section{Conclusions and suggestions}

\subsection{Conclusion}

Through the empirical analysis, it is found that the overall development trend of green finance in China is good, but there is a slowdown trend. The increase of green credit can improve the efficiency of capital allocation and promote the economic transformation and upgrading and sustainable development. The financial needs such as financing needs and security needs caused by economic development will further promote the development of green credit. As a new mode to realize green development, green finance takes into account both environmental benefits and enterprise economic benefits, which is an important means to promote sustainable economic development.

\subsection{Suggestions}

\subsubsection{Increase the application proportion of green finance}

In order to give full play to the role of green finance in promoting the economy, it is necessary to improve the application rate of green finance and strengthen the positive incentive mechanism of green finance. Although China's green finance has achieved initial results, it is still in the primary stage, and its development needs to be further deepened. On the one hand, accelerate the development of green financial market, unify internal and external green financial standards, and promote the consistency and comparability of green standards; On the other hand, we should coordinate industrial policy and financial policy, increase the proportion of green industry in industrial structure adjustment, and take green financial investment standard as the reference standard of industrial development.

\subsubsection{Improve green financial products and business model}

In order to activate the vitality of green financial market and improve the development mode of green finance. On the basis of stabilizing the basic business mechanism of green credit, we should explore and improve green credit business development, process management and other aspects, clarify the green credit risk management strategy, allow green enterprises to provide various kinds of pledge, such as intellectual property rights, export tax rebate, carbon emission rights, and give priority to enterprises that meet the green standards. At the same time, we should continue to innovate green financial tools, improve China's green investment and financing mechanism, and promote the diversified development of green financial business model. We should issue green bonds, improve the financing capacity of the green bond market, support more social capital and international capital flow to the green environmental protection industry, expand the scale of the green bond market, and encourage project entities to refinance green projects. Promote green insurance, give full play to the re guarantee function of green insurance, provide protection for investors and offset their investment concerns. We should issue the green fund for sustainable development, establish the mechanism of public participation, and realize the value maintenance, appreciation and sustainable growth of capital.

\subsubsection{Form a market mechanism for green finance to promote green development independently}

The key for green finance to support green recovery is to form a market-oriented environment in which finance independently promotes green development, transform the government guided green development into a market driven one, give full play to market forces, truly transform ecological benefits into economic benefits, and help sustainable economic development. We should build an ecological economic system suitable for the carrying capacity of natural resources, build and improve the supply system of green financial products and the value realization mechanism, so as to bring power for green finance to promote economic recovery.

\section{References}

1. Wang Xiuhua, Liu Na. Long term mechanism of sustainable development of green finance in China. Theoretical Exploration, 2016 (04): 99-105

2. Zhou Lei, an Ye. Green finance and sustainable development. People 's Forum, 2018 (18): 84-85

3. Ma Jun. development and Prospect of green finance in China. Comparison of Economic and Social Systems, 2016 (06): 25-32

4. Ding pan, Jin Weihua, Chen Nan. Green finance development, industrial structure upgrading and sustainable economic growth. Southern Finance, 2021 (02): 13-24

5. Ma Jun, Meng Haibo, Shao Danqing, Zhu Yashan. Green finance, Inclusive Finance and green agriculture development. Financial Forum, 2021.26 (03): $3-8+20$

6. He Xi. The origin, development and global practice of green finance. Journal of Southwest University (Social Science Edition), 2021.47 (01): 83-94 + 226 